DOI: https://doi.org/10.24127/ajpm.v10i4.4403

\title{
KEMAMPUAN PEMECAHAN MASALAH MATEMATIS DITINJAU DARI SELF CONFIDENCE SISWA
}

\author{
Gemi Susanti $^{1^{*}}$, Chairuddin ${ }^{2}$ \\ ${ }^{1 *, 2}$ Universitas Sembilanbelas November Kolaka, Kolaka, Indonesia \\ *Corresponding author. \\ E-mail: $\quad \frac{\text { gemisusantimath@gmail.com }}{\text { chairuddin.spd @gmail.com }^{2)}}$
}

Received 04 November 2021; Received in revised form 16 November 2021; Accepted 23 December 2021

\begin{abstract}
Abstrak
Penelitian ini dilatarbelakangi pada rendahnya kemampuan pemecahan masalah matematis siswa, dimana kebanyakan orang menyalahkan model pembelajarannya sedangkan terdapat banyak faktor yang mempengaruhi hal tersebut, salah satunya adalah self confidence (kepercayaan diri) siswa. Penelitian ini bertujuan untuk mengetahui perbedaan kemampuan pemecahan masalah matematis siswa ditinjau dari self confidence. Jenis penelitian ini adalah penelitian expost-facto dengan menggunakan sampel sebanyak 48 orang siswa Mts. Data dalam penelitian ini diperoleh melalu teknik tes, yang selanjutnya dianalisis menggunakan statistik deskriptif dan analisis inferensial menggunakan anova satu jalur. Dari hasil analisis yang dilakukan diperoleh rata-rata kemampuan pemecahan masalah siswa adalah 50,94 yang mana jika dikonversi maka nilai tersebut berada pada kategori kurang. Selanjutnya dari analisis inferensial diperoleh $F_{\text {Hitung }}>F_{\text {Tabel }}$ sehingga dapat disimpulkan terdapat perbedaan yang signifikan kemampuan pemecahah masalah matematis antara siswa dengan Self Confidence sangat tinggi, tinggi, sedang dan rendah. hasil ini berarti siswa dengan Self Confidence akan memiliki kemampuan pemecahan masalah yang berbeda pula. Selanjtnya dari hasil analisis lanjut diperoleh kesimpulan bahwa siswa dengan self confidence sangat tinggi memiliki kemampuan pemecahan masalah yang lebih baik dibandingkan dengan siswa lainnya.
\end{abstract}

Kata kunci: Kemampuan pemecahan masalah, self-confidence.

\begin{abstract}
This research is motivated by the low mathematical problem solving ability of students, where most people blame the learning model while there are many factors that influence this, one of which is students' self confidence. This study aims to determine the differences in students' mathematical problem solving abilities in terms of self-confidence. This type of research is an expost-facto research using a sample of 48 students of Mts. The data in this study were obtained through a test technique, which was then analyzed using descriptive statistics and inferential analysis using one-way ANOVA. From the results of the analysis carried out, it was obtained that the average problem-solving ability of students was 50.94 which if converted, the value was in the less category. Furthermore, from the inferential analysis obtained $F_{\text {Hitung }}>F_{\text {Tabel }}$ so that it can be concluded that there are significant differences in mathematical problem solving abilities between students with very high, high, medium and low Self Confidence. This result means that students with Self Confidence will have different problem solving abilities. Furthermore, from the results of further analysis, it was concluded that students with very high self-confidence had better problem-solving abilities than other students
\end{abstract}

Keywords: Problem Solving Ability, self-confidence

This is an open access article under the Creative Commons Attribution 4.0 International License 
DOI: https://doi.org/10.24127/ajpm.v10i4.4403

\section{PENDAHULUAN}

Matematika adalah salah satu mata pelajaran yang dipelajari disemua jenjang pendidikan (Tahir, 2021). Dalam mempelajari matematika siswa banyak diarahkan dalam menyelesaikan soal-soal ataupun permasalahanpemasalahan yang berkaitan dengan kehidupan sehari-hari atau masalah nyata. Sebab dengan melakukan kegiatan memecahkan masalah secara berulang-ulang dapat membuat siswa menemukan alternatif penyelesaian masalah yang banyak(Anditiasari, 2020; Sari, 2017). Hal ini sejalan dengan pendapat Mc Kinnon yang menyatakan bahwa seseorang yang menemukan solusi baru akan menghasilkan banyak ide (Marliani, 2015). Olehnya itu, dalam belajar matematika siswa dituntut untuk memiliki kemampuan pemecahan masalah yang baik (Tahir \& Marniati, 2019). Kemampuan pemecahan masalah matematis merupakan kemampuan yang meliputi kemampuan siswa memahami masalah, menguasai masalah, merancang model matematika dan menyelesaikan soal pemecahan masalah matematika yang diberikan dengan cara berfikir yang lebih kompleks(Cahyani \& Setyawati, 2016; Sumartini, 2018; Tahir \& Kurniawan, 2020).

$\begin{array}{cr}\text { Realitanya } & \text { dilapangan } \\ \text { kemampuan pemecahan masalah }\end{array}$ matematika siswa masih tergolong rendah, seperti hasil penelitian dari Asih \& Ramadhani (2019), Hasanah et al. (2019), Mulyati (2016), L. Sari \& Maidiyah (2019), Sumartini (2018) yang menyimpulkan bahwa kemampuan pemecahan masalah siswa masih tergolong lemah atau rendah. Hal ini juga terjadi di MTs Negeri 2 Kolaka dari hasil wawancara yang dilakukan diperoleh informasi bahwa masih banyak siswa yang belum mampu memecahkan masalah matematis yang penyelesainnya menuntut perencanaan dengan mengaitkan dunia nyata atau kehidupan sehari-hari. Selain itu ketika siswa diberikan soal cerita siswa kesulitan menyelesaikan soal dalam bahasa matematika atau bahasa sendiri dan juga siswa kesulitan dalam penggunaan simbol matematika yang sesuai. Hal tersebut menunjukkan bahwa kemampuan pemecahan masalah matematis siswa masih rendah.

Telah banyak penelitian yang dilakukan untuk mengatasi hal tersebut, namun kebanyakan penelitian-penelitian tersebut lebih kepada model pembelajaran yang diterapkan oleh guru di sekolah yang mana ini merupakan faktor eksternal untuk membantu siswa dalam berprestasi. Sedangkan kita ketahui bahwa dalam berprestasi siswa tidak hanya dipengaruhi oleh faktor eksternal tetapi juga faktor internal siswa (Tahir \& Marniati, 2018). Sehingga perlu juga diperhatikan faktor internalnya juga.

Salah satu faktor internal yang perlu diperhatikan adalah selfconfidence (kepercayaan diri) karena kemampuan pemecahan masalah erat kaitannya dengan kepercayaan diri siswa dalam menyelesaikan soal (Aisyah et al., 2018). Hannula, Maijah \& Pohkonen menyatakan bahwa siswa dengan self confidence yang baik, akan sukses dalam belajar matematika (Purwasih, 2015). Karena siswa tersebut akan cenderung memahami, menemukan, dan memperjuangkan masalah matematika yang dihadapinya untuk menemukan solusi yang diharapkan. Sehingga akan menjadikan individu yang berhasil terutama dalam hal pembelajaran, demikian pula sebaliknya (Fardani \& Surya, 2018; Marasabessy, 2020; Purnama \& Mertika, 2018). 
DOI: https://doi.org/10.24127/ajpm.v10i4.4403

Olehnya itu dibutuhkan suatu penelitian untuk mengetahui kemampuan pemecahan masalah yang ditinjau dari self confidence, yang dapat memberikan informasi ataupun dasar untuk meningkatkan kemampuan pemecahan masalah yang kaitannya dengan self confidence. Sehingga penelitian ini dilakukan dengan tujuan untuk melihat perbedaan dari kemampuan pemecahan masalah matematis siswa di MTs Negeri 2 Kolaka ditinjau dari self confidence.

\section{METODE PENELITIAN}

Penelitian ini dilakukan dengan menggunakan metode expost-facto. penelitian yang dilakukan dengan pengkajian mengenai perbedaan kemampuan pemecahan masalah matematis ditinjau dari self confidence siswa. Penelitian ini dilaksanakan di kelas VIII di MTs Negeri 2 Kolaka. Sampel pada penelitian ini adalah 48 orang siswa yang dipilih secara random.

Pada penelitian ini Data diperoleh melalui dua cara yaitu menggunakan metode kuesioner (angket) untuk memperoleh data self confidence. Sedangkan untuk memperoleh data kemampuan pemecahan masalah siswa digunakan soal tes kemampuan pemecahan masalah. Soal tes maupun angket yang telah diuji coba terlebih dahulu, untuk dilihat validitas, reabilitias maupun tingkat kesukaran dan daya pembeda soalnya.

Data self confidence siswa dibuatkan tabel klasifikasi menurut aturan Tabel 1.
Tabel 1. Aturan konversi data self confidence siswa

\begin{tabular}{cc}
\hline Interval & Kriteria \\
\hline $\mathrm{Mi}+1,5 \mathrm{Si}<\mathrm{X} \leq \mathrm{Mi}+3 \mathrm{Si}$ & Sangat Tinggi \\
$\mathrm{Mi}+0,5 \mathrm{Si}<\mathrm{X} \leq \mathrm{Mi}+1,5 \mathrm{Si}$ & Tinggi \\
$\mathrm{Mi}-0,5 \mathrm{Si}<\mathrm{X} \leq \mathrm{Mi}+0,5 \mathrm{Si}$ & Sedang \\
$\mathrm{Mi}-1,5 \mathrm{Si}<\mathrm{X} \leq \mathrm{Mi}-0,5 \mathrm{Si}$ & Rendah \\
$\mathrm{Mi}-3 \mathrm{Si}<\mathrm{X} \leq \mathrm{Mi}-1,5 \mathrm{Si}$ & Sangat Rendah \\
\hline
\end{tabular}

Dengan

Mi = Rerata Skor Ideal

$\mathrm{Si}=$ Standar Deviasi Ideal

$X \quad=$ Total Skor Aktual

Sedangkan untuk data kemampuan pemecahan maslah matematis siswa dianalisis secara deskriptif, dan diklasifikasikan sesuai Tabel 2.

Tabel 2. Klasifikasi kemampuan pemecahan masalalah matematis

\begin{tabular}{cc}
\hline Nilai (N) & Klasifikasi \\
\hline $85 \leq N \leq 100$ & Sangat Baik \\
$70 \leq N<85$ & Baik \\
$55 \leq N<70$ & Cukup \\
$40 \leq N<55$ & Kurang \\
$0 \leq N<40$ & Sangat Kurang \\
\hline & (Mawaddah, 2015)
\end{tabular}

Untuk melihat perbedaan dari kemampuan pemecahan masalah berdasarkan self confidence siswa dilakukan uji anova 1 jalur dengan terlebih dahulu melakukan uji normalitas. Rumus anova satu jalur dapat dilihat di Tabel 3. Jika terdapat perbedaan maka dilakukan uji lanjut menggunakan uji Dunnet atau Scheffe.

Tabel 3. Anova satu jalur

\begin{tabular}{|c|c|c|c|c|c|c|}
\hline $\begin{array}{l}\text { Sumber } \\
\text { Varians }\end{array}$ & $\begin{array}{l}\text { Jumlah } \\
\text { (JK) }\end{array}$ & Kuadrat & $\begin{array}{c}\text { Derajat } \\
\text { Bebas (db) }\end{array}$ & $\begin{array}{c}\text { Kuadrat } \\
\text { Rerata (KR) }\end{array}$ & $F_{\text {Hitung }}$ & $\boldsymbol{F}_{\text {Tabel }}$ \\
\hline $\begin{array}{l}\text { Antar } \\
\text { Grup } \\
\text { (A) }\end{array}$ & $J K(A)=$ & & & $R J K(A)=\frac{J K}{d l}$ & $\frac{R J K(A)}{R J K(D)}$ & $\begin{array}{l}\text { Dilihat pada } \\
\text { tabel F dengan } \\
\alpha=0,05\end{array}$ \\
\hline
\end{tabular}


DOI: https://doi.org/10.24127/ajpm.v10i4.4403

\begin{tabular}{|c|c|c|c|c|c|c|}
\hline $\begin{array}{l}\text { Sumber } \\
\text { Varians }\end{array}$ & $\begin{array}{l}\text { Jumlah } \\
\text { (JK) }\end{array}$ & Kuadrat & $\begin{array}{c}\text { Derajat } \\
\text { Bebas (db) }\end{array}$ & $\begin{array}{c}\text { Kuadrat } \\
\text { Rerata (KR) }\end{array}$ & $F_{\text {Hitung }}$ & $\boldsymbol{F}_{\text {Tabel }}$ \\
\hline $\begin{array}{l}\text { Dalam } \\
\text { Grup } \\
\text { (D) }\end{array}$ & $J K(D)=$ & $\sum_{i=1}^{n_{i}} Y_{i}^{2}-\frac{\left(\sum_{i=1}^{n_{i}} Y_{i}\right.}{n_{i}}$ & & & & \\
\hline Total & & $\left(\sum_{t}^{n_{t}} Y_{t}\right)^{2}$ & $n_{t}-1$ & & & \\
\hline
\end{tabular}

(Tahir, 2021)

Tabel 4. Hasil Klasifikasi Self Confidence Siswa

\begin{tabular}{cccc}
\hline Interval & Kriteria & Frekuensi & Persentase \\
\hline $64<X \leq 80$ & Sangat Tinggi & 9 & $19 \%$ \\
$53,33<X \leq 64$ & Tinggi & 16 & $33 \%$ \\
$42,67<X \leq 53,33$ & Sedang & 16 & $33 \%$ \\
$32<X \leq 42,67$ & Rendah & 7 & $15 \%$ \\
$0<X \leq 32$ & Sangat Rendah & 0 & $0 \%$ \\
\hline & & $\mathbf{4 8}$ & $\mathbf{1 0 0 \%}$ \\
\hline
\end{tabular}

\section{HASIL DAN PEMBAHASAN}

Hasil pemberian angket kepada sampel penelitian, selanjutnya di analisis dan diklasifikasikan sesuai tabel 2. Dan diperoleh hasil pada Tabel 4. Berdasarkan Tabel 4 dapat dilihat bahwa dari 48 orang siswa yang menjadi sample penelitian tidak ada siswa yang memiliki Self Confidence kategori sangat rendah, 7 orang atau $15 \%$ siswa yang memiliki Self Confidence kategori rendah dan 16 orang atau $33 \%$ siswa memiliki Self Confidence pada kategori sedang . Sedangkan pada kategori tinggi terdapat 16 orang atau $33 \%$ siswa dan 9 orang atau $19 \%$ siswa berada pada kategori sangat tinggi, yang jika ditotal untuk kategori tinggi dan sangat tinggi diperoleh 25 orang atau $52 \%$.

Selanjutnya, untuk data hasil tes kemampuan pemecahan masalah siswa yang telah dianalisis diklasifikasikan berdasarkan tabel 3 yang dapat dilihat pada Tabel 5.
Tabel 5. Klasifikasi kemampuan pemecahan masalah matematis siswa

\begin{tabular}{ccc}
\hline Kriteria & Frekuensi & Persentase \\
\hline Sangat Baik & 0 & $0 \%$ \\
Baik & 6 & $13 \%$ \\
Cukup & 14 & $29 \%$ \\
Kurang & 14 & $29 \%$ \\
Sangat & & \\
Kurang & 14 & $29 \%$ \\
\hline Jumlah & $\mathbf{4 8}$ & $\mathbf{1 0 0 \%}$ \\
\hline
\end{tabular}

Berdasarkan tabel 5. Diperoleh bahwa dari 48 orang siswa yang dijadikan sebagai sample penelitian, tidak ada siswa yang memiliki kemampuan pemecahan masalah pada kategori sangat baik dan kategori baik terdapat 6 orang siswa atau 13\%, Sedangkan untuk kategori cukup terdapat 14 orang siswa atau $29 \%$. Sedangkan terdapat 14 orang siswa atau $29 \%$ berada pada kategori kurang maupun sangat sangat kurang yang jika dijumlahkan diperoleh $58 \%$ siswa memiliki kemampuan pemecahan 
masalah yang kurang baik. Selanjut dilakukan analisis statistik deskriptif yang hasilnya dapat dilihat di Tabel 6 .

Tabel 6. Hasil analsis deskriptif kemampuan pemecahan masalah

\begin{tabular}{lr}
\hline Statistik Deskriptif & \multicolumn{1}{c}{ Nilai } \\
\hline Mean & 50,94 \\
Median & 48,75 \\
Mode & 42,5 \\
Standard Deviation & 17,76 \\
Sample Variance & 315,34 \\
Range & 72,5 \\
Minimum & 10 \\
Maximum & 82,5 \\
Sum & 2445 \\
Count & 48 \\
\hline
\end{tabular}

Dari tabel 6 dapt dilihat bahwa rata-rata kemampuan pemecahan masalah siswa adalah 50,94 yang mana jika dikonversi pada tabel 2 maka nilai tersebut berada pada kategori kurang hal ini sesuai dengan hasil pada tabel 5 . Begitupula jika kita melihat ukuran mode atau modus pada tabel 6 di atas, yang mana pada ukuran ini diperoleh nilai 42,5 yang berarti bahwa siswa terbanyak memiliki kemampuan pemecahan masalah kategori kurang. Selanjutnya dilakukan analisis deskriftip berdasarkan Self Confidence siswa, dan hasilnya dapat dilihat pada Gambar 1.

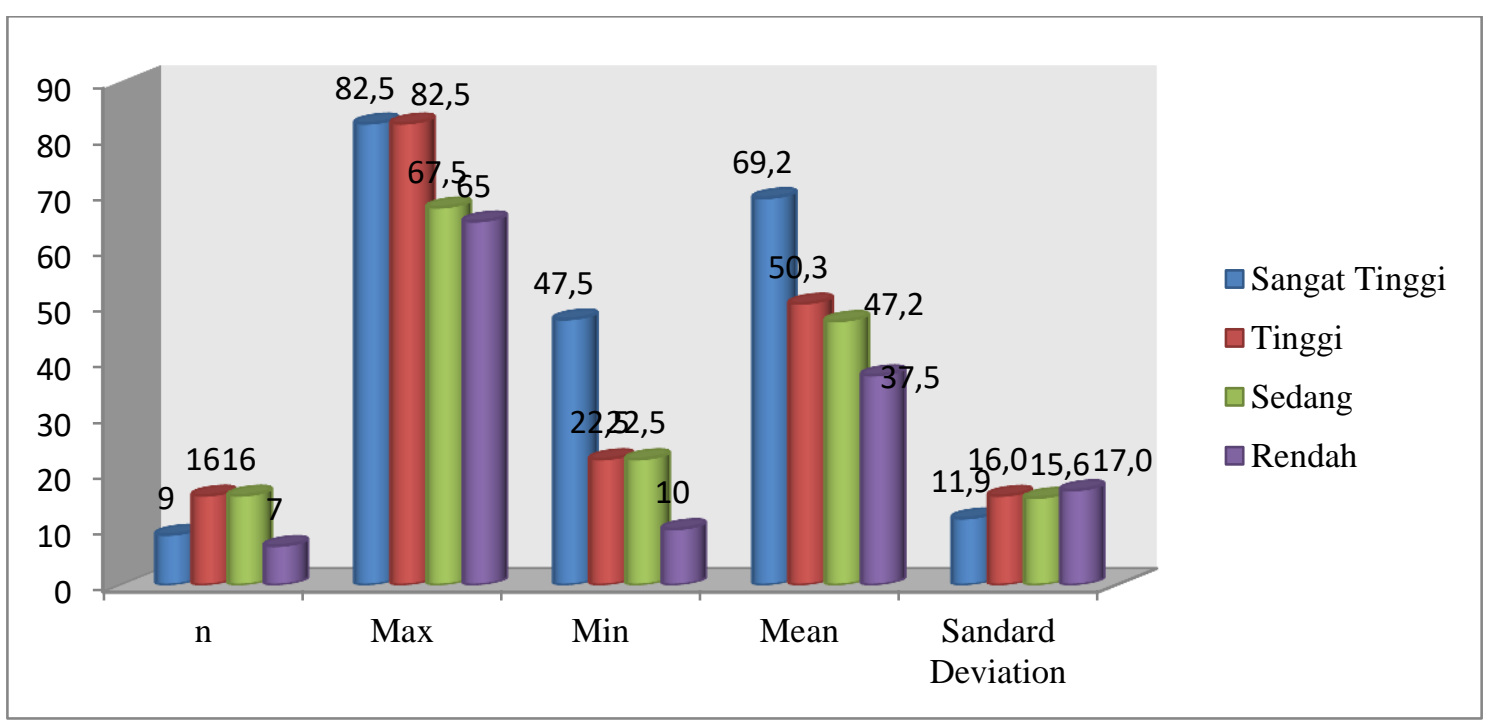

Gambar 1 Hasil analisis deskriftip kemampuan pemacahan masalah matematis ditinjau dari self confidence siswa

Berdasarkan gambar 1 diperoleh bahwa rata-rata kemampuan pemecahan masalah matematis siswa dengan kategori Self Confidence sangat tinggi adalah 69,2 yang mana ini berada pada kategori cukup. Siswa dengan Self Confidence kategori tinggi memiliki rata-rata 50,3 atau berada pada kategori kurang sama halnya untuk siswa dengan Self Confidence kategori sedang juga memiliki rata-rata 47,2 atau kategori kurang. Sedangkan siswa dengan Self Confidence kategori rendah memiliki rata-rata kemampuan pemecahan masalah 37,5 atau kategori sangat kurang. Sehingga dari informasi tersebut dapat dilihat bahwa semakin baik Self Confidence siswa maka semakin baik kemampuan pemecahan masalah matematisnya. 
DOI: https://doi.org/10.24127/ajpm.v10i4.4403

Selanjutnya, untuk melihat perbedaan kemampuan pemecahan masalah matematis berdasarkan Self Confidence siswa dilakukan analisis inferensial dengan menggunakan uji Anova 1 jalur, dengan terlebih dahulu melakukan uji normalitas data dengan menggunakan uji kolmogorov-smirnov sebagai uji prasyaratnya. Hasil uji normalitas data dapat dilihat pada Tabel 7.

Tabe 7. Hasil Uji Normalitas data

\begin{tabular}{lcccl}
\hline \multicolumn{1}{c}{ Kelompok } & n & Dhit & Dtab & Kesimpulan \\
\hline Sangat Tinggi & 9 & 0,1945 & 0,430 & Data Normal \\
Tinggi & 16 & 0,1324 & 0,327 & Data Normal \\
Sedang & 16 & 0,1693 & 0,327 & Data Normal \\
Rendah & 7 & 0,2412 & 0,483 & Data Normal \\
\hline
\end{tabular}

Dari tabel 7 diperoleh bahwa semua kelompok data berdistribusi normal sehingga uji anova satu jalur dapat dilakukan, dengan hipotesis sebagai berikut:

$\mathrm{H}_{0}=$ tidak terdapat perbedaan yang signifikan kemampuan pemecahah masalah matematis antara siswa dengan Self
Confidence sangat tinggi, tinggi, sedang dan rendah.

$\mathrm{H}_{1}=$ terdapat perbedaan yang signifikan kemampuan pemecahah masalah matematis antara siswa dengan Self Confidence sangat tinggi, tinggi, sedang dan rendah.

Hasil uji anova satu jalur dapat dilihat pada Tabel 8.

Tabel 8. Ringkasan Hasil Uji Anova Satu Jalur

\begin{tabular}{lccccc}
\hline \multicolumn{1}{c}{$\begin{array}{c}\text { Sumber } \\
\text { Varians }\end{array}$} & $\begin{array}{c}\text { Jumlah } \\
\text { Kuadrat }(\mathbf{J K})\end{array}$ & $\begin{array}{c}\text { Derajat } \\
\text { Bebas }(\mathbf{d b})\end{array}$ & $\begin{array}{c}\text { Kuadrat } \\
\text { Rerata }(\mathbf{K R})\end{array}$ & $\boldsymbol{F}_{\text {Hitung }}$ & $\boldsymbol{F}_{\text {Tabel }}$ \\
\hline Antar group (A) & 4485,94 & 3 & 149,31 & 6,37 & 2,82 \\
Dalam group (D) & 10334,38 & 44 & 234,87 & & \\
Total & 14820.31 & 47 & 315,33 & & \\
\hline
\end{tabular}

Dari tabel 8 diperoleh bahwa $F_{\text {Hitung }}>F_{\text {Tabel }}$ sehingga $\mathrm{H} 0$ ditolak dan H1 diterima dalam artian terdapat perbedaan yang signifikan kemampuan pemecahah masalah matematis antara siswa dengan Self Confidence sangat tinggi, tinggi, sedang dan rendah.
Selanjutnya dilakukan uji lanjut untuk melihat tingkatan self-confidence siswa yang terbaik. Namun terlebih dahulu dilakukan uji homogenitas, untuk menentukan jenis uji lanjut yang akan digunakan. Uji homogenitas yang digunakan adalah uji Bartlet, yang hasilnya dapat dilihat pada Tabel 9.

Tabel 9 Hasil Uji Homogenitas Data.

\begin{tabular}{ccccccc}
\hline Uji & $\mathbf{k}$ & $\chi_{\text {hit }}^{2}$ & $\mathbf{d b}$ & $\alpha$ & $\chi_{\text {tab }}^{2}$ & Kesimpulan \\
\hline Bartlet & 4 & 1,05 & 3 & 0,05 & 7,82 & homogen \\
\hline
\end{tabular}


DOI: https://doi.org/10.24127/ajpm.v10i4.4403

Berdasarkan tabel 9 diperoleh bahwa data memiliki varians yang homogen sehingga uji lanjut yang digonakan adalah uji uji t Dunnet. Hasil uji $\mathrm{t}$ Dunnet dengan hipotesis $H_{0}: \mu_{i} \leq \mu_{j}$ dan $H_{a}: \mu_{i}>\mu_{j}$ untuk $\mathrm{i}, \mathrm{j}=$ 1, 2, 3, 4 ditampilkan pada Tabel 10.

Tabel 10. Hasil Uji t Dunnet

\begin{tabular}{cccc}
\hline No & Variabel & $t_{h i t}$ & $t_{\text {tab }}$ \\
\hline 1 & $Y_{1}-Y_{2}$ & 2,95 & \\
2 & $Y_{1}-Y_{3}$ & 3,44 & \\
3 & $Y_{1}-Y_{4}$ & 4,10 & 2,02 \\
4 & $Y_{2}-Y_{3}$ & 0,58 & \\
5 & $Y_{2}-Y_{4}$ & 8,85 & \\
6 & $Y_{3}-Y_{4}$ & 1,39 & \\
\hline
\end{tabular}

Dari tabel 10 dapat ditentukan hasil sebagai berikut.

1. Untuk $Y_{1}$ dan $Y_{2}$ diperoleh $t_{h i t}>t_{t a b}$ maka $H_{0}$ ditolak dalam artian kemampuan pemecahan masalah matematis siswa yang memiliki selfconfidence sangat tinggi, lebih baik dari kemampuan pemecahan masalah matematis siswa yang memiliki selfconfidence tinggi.

2. Untuk $Y_{1}$ dan $Y_{3}$ diperoleh $t_{h i t}>t_{t a b}$ maka $H_{0}$ ditolak dalam artian kemampuan pemecahan masalah matematis siswa yang memiliki selfconfidence sangat tinggi, lebih baik dari kemampuan pemecahan masalah matematis siswa yang memiliki selfconfidence sedang.

3. Untuk $Y_{1}$ dan $Y_{4}$ diperoleh $t_{h i t}>t_{t a b}$ maka $H_{0}$ ditolak dalam artian kemampuan pemecahan masalah matematis siswa yang memiliki selfconfidence sangat tinggi, lebih baik dari kemampuan pemecahan masalah matematis siswa yang memiliki selfconfidence rendah.
4. Untuk $Y_{2}$ dan $Y_{3}$ diperoleh $t_{h i t} \leq t_{\text {tab }}$ maka $H_{0}$ diterima dalam artian kemampuan pemecahan masalah matematis siswa yang memiliki selfconfidence tinggi, tidak lebih baik dari kemampuan pemecahan masalah matematis siswa yang memiliki selfconfidence sedang.

5. Untuk $Y_{2}$ dan $Y_{4}$ diperoleh $t_{h i t}>t_{t a b}$ maka $H_{0}$ ditolak dalam artian kemampuan pemecahan masalah matematis siswa yang memiliki selfconfidence tinggi, lebih baik dari kemampuan pemecahan masalah matematis siswa yang memiliki selfconfidence rendah.

6. Untuk $Y_{3}$ dan $Y_{4}$ diperoleh $t_{h i t} \leq t_{t a b}$ maka $H_{0}$ diterima dalam artian kemampuan pemecahan masalah matematis siswa yang memiliki selfconfidence sedang, tidak lebih baik dari kemampuan pemecahan masalah matematis siswa yang memiliki selfconfidence rendah.

Berdasarkan hasil analisis data deskriftip yang dilakukan diperoleh bahwa siswa di MTs Negeri 2 Kolaka memiliki self-confidence kategori baik namun memiliki kemampuan pemecahan masalah matematis yang tergolong rendah. Hasil ini sejalan dengan hasil penelitian dari Asih \& Ramadhani (2019), Hasanah et al. (2019), Mulyati (2016), L. Sari \& Maidiyah (2019), Sumartini (2018) yang juga memperoleh hasil yang sama pada penelitian mereka.

Hasil analisis inferensial diperoleh bahwa terdapat perbedaan yang signifikan kemampuan pemecahah masalah matematis antara siswa dengan Self Confidence sangat tinggi, tinggi, sedang dan rendah. hasil ini berarti siswa dengan Self Confidence akan memiliki kemampuan pemecahan 
masalah yang berbeda pula. hal ini sejalan dengan pendapat dari Aisyah et al. (2018), yang mengatakan bahwa self-confidence berkaitan erat dengan kemampuan pemecahan masalah. Selanjutnya dari hasil uji lanjut diperoleh bahwa siswa yang memiliki self-confidence pada kategori sangat tinggi memiliki kemampuan pemecahan masalah matematis lebih baik dibandingkan dengan siswa dengan selfconfidence tinggi, sedang maupun rendah. hal ini berarti semakin tinggi rasa kepercayaan diri seorang siswa maka semakin baik pula kemampuannya dalam menyelesaikan masalah matematis yang diberikan. Hasil ini sesuai dengan pendapat dari Hannula, Maijah \& Pohkonen menyatakan bahwa siswa dengan self confidence yang baik, akan sukses dalam belajar matematika. Diperkuat oleh pernyataan dari Fardani \& Surya, 2018; Marasabessy, 2020; Purnama \& Mertika, 2018 siswa dengan self confidence yang baik akan cenderung memahami, menemukan, dan memperjuangkan masalah matematika yang dihadapinya untuk menemukan solusi yang diharapkan.

\section{KESIMPULAN DAN SARAN}

Dari hasil penelitian dipoeroleh rata-rata kemampuan pemecahan masalah matematis siswa tergolong rendah dengan self confidence siswa tergolong baik. Selanjutnya dari analisis inferensial diperoleh $\quad F_{\text {Hitung }}>\quad F_{\text {Tabel }}$ sehingga dapat disimpulkan terdapat perbedaan yang signifikan kemampuan pemecahah masalah matematis antara siswa dengan Self Confidence sangat tinggi, tinggi, sedang dan rendah. hasil ini berarti siswa dengan Self Confidence akan memiliki kemampuan pemecahan masalah yang berbeda pula dari hasil analisis lanjut diperoleh kesimpulan bahwa siswa dengan self confidence sangat tinggi akan memiliki kemampuan pemecahan masalah yang lebih baik dibandingkan dengan siswa lainnya.

Untuk peneliti selanjutnya diharapkan didalam penelitiannya selain meningkatkan kemampuan pemecahan masalah matematis juga dapat meningkatkan self-confidence ata kepercayaan diri siswa.

\section{DAFTAR PUSTAKA}

Aisyah, P. N., Nuraini, N., Akbar, P., \& Yuliani, A. (2018). Analisis Hubungan Kemampuan Pemecahan Masalah Matematis Dan Self Confidence Siswa Smp. Journal On Education, 1(1), 5865.

Anditiasari, N. (2020). Analisis Kesulitan Belajar Abk (Tuna Rungu) Dalam Menyelesaikan Soal Cerita Matematika. Mathline: Jurnal Matematika Dan Pendidikan Matematika, 5(2), 183-194. https://doi.org/10.31943/mathline. v5i2.162

Asih, N., \& Ramadhani, S. (2019). Peningkatan Kemampuan Pemecahan Masalah Matematis dan Kemandirian Belajar Siswa Menggunakan Model Pembelajaran Means End Analysis. Jurnal Pendidikan Matematika, 8(3), 435-446. https://journal.institutpendidikan.a c.id/index.php/mosharafa/article/v iew/mv8n3_8

Cahyani, H., \& Setyawati, R. W. (2016). Pentingnya Peningkatan Kemampuan Pemecahan Masalah Melalui PBL untuk Mempersiapkan Generasi Unggul Menghadapi MEA. PRISMA, Prosiding Seminar Nasional 
DOI: https://doi.org/10.24127/ajpm.v10i4.4403

Matematika, 151-160.

Fardani, Z., \& Surya, E. (2018). Pembelajaran Matematika Melalui Model Problem Based Learning. 39-51.

Hasanah, E., Darmawan, D., \& Nanang. (2019). Pengaruh Penggunaan Media Pembelajaran Articulate dalam Metode Problem Based Learning (PBL) terhadap Peningkatan Kemampuan Berpikir Kreatif Peserta Didik. JTEP-Jurnal Teknologi Pendidikan Dan Pembelajaran, 4(1), 826-838. https://journal.institutpendidikan.a c.id/index.php/tekp/article/view/5 03

Marasabessy, R. (2020). Kajian Kemampuan Self Efficacy Matematis Siswa Dalam Pemecahan Masalah Matematika. JARTIKA Jurnal Riset Teknologi Dan Inovasi Pendidikan, 3(2), 168-183.

https://doi.org/10.36765/jartika.v3 i2.17

Marliani, N. (2015). Peningkatan Kemampuan Berpikir Kreatif Matematis Siswa melalui Model Pembelajaran Missouri Mathematics Project (MMP). Formatif: Jurnal Ilmiah Pendidikan MIPA, 5(1), 14-25. https://doi.org/10.30998/formatif. v5i1.166

Mulyati, T. (2016). Kemampuan Pemecahan Masalah Matematis Siswa Sekolah Dasar (Mathematical Problem Solving Ability of Elementary School Students). EDUHUMANIORA: Jurnal Pendidikan Dasar, 3(2), 120.

Purnama, S., \& Mertika, M. (2018). Analisis Kemampuan Pemecahan Masalah Siswa Ditinjau dari Self
Confidence. Journal of Educational Review and Research, 1(2), 59. https://doi.org/10.26737/jerr.v1i2. 1619

Purwasih, R. (2015). Peningkatan Kemampuan Pemahaman Matematis Dan Self Confidence Siswa MTs Di Kota Cimahi Melalui Model Pembelajaran Inkuiri Terbimbing. Jurnal Ilmiah STKIP Siliwangi Bandung, 9(1), 16-25. http://ejournal.stkipsiliwangi.ac.id/index. php/didaktik/issue/view/18

Sari, L., \& Maidiyah, E. (2019). Proses Pemecahan Masalah Matematis Siswa Smp Materi Bentuk Aljabar Melalui Model Problem-Based Learning. Jurnal Peluang, 7(2), 77-84.

https://doi.org/10.24815/jp.v7i2.1 5099

Sari, P. (2017). Pemahaman Konsep Matematika Siswa pada Materi Besar Sudut Melalui Pendekatan PMRI. Jurnal Gantang, 2(1), 4150.

https://doi.org/10.31629/jg.v2i1.6 0

Siti Mawaddah, H. A. (2015). Kemampuan Pemecahan Masalah Matematis Siswa Pada Pembelajaran Matematika Dengan Menggunakan Model Pembelajaran Generatif (Generative Learning) Di SMP. 3, 166-175.

Sumartini, T. S. (2018). Peningkatan Kemampuan Pemecahan Masalah Matematis Siswa melalui Pembelajaran Berbasis Masalah. Mosharafa: Jurnal Pendidikan Matematika, 5(2), 148-158. https://doi.org/10.31980/mosharaf a.v5i2.270 
DOI: https://doi.org/10.24127/ajpm.v10i4.4403

Tahir, \& Kurniawan, P. (2020). Penerapan Model Pembelajaran Penemuan Terbimbing Terhadap Peningkatan Kemampuan Pemecahan Masalah Matematis Mahasiswa. Scientific African, 114(June), e00146. https://doi.org/10.1016/j.sciaf.201 9.e00146

Tahir, \& Marniati. (2019). Penerapan Metode Scamper Dalam Mengembangkan Kemampuan Pemecahan Masalah Ditinjau Dari Motivasi Mahasiswa Pendidikan Matematika Universitas Sembilanbelas November Kolaka. 4(2), 43-48.

Tahir, T. (2021). The Effect of Learning Styles on Students ' Mathematical Communication Ability. Journal of Medives: Journal of Mathematics Education IKIP Veteran Semarang, 5(1), 13-21. https://doi.org/10.31331/medivesv eteran.v5i1.1378

Tahir, T., \& Marniati, M. (2018). Pengaruh Kreativitas terhadap Prestasi Belajar Matematika Siswa ditinjau dari Jenis Kelamin (Studi Kasus di MAN 1 Kolaka). Journal of Medives: Journal of Mathematics Education IKIP Veteran Semarang, 2(2), 279284.

https://doi.org/10.31331/medives. v2i2.656 